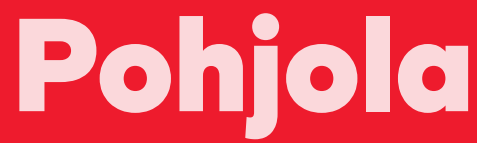

tilestoine

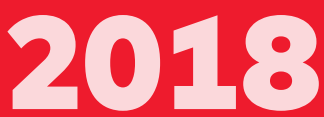

III) Pohjoismaiden ministerineuvosto 


\section{Pohjola tilastoina 2018}

Toimittanut: Ulla Agerskov ja Silva Mertsola,

Pohjoismaiden ministerineuvosto

ANP 2018:820

ISBN 978-92-893-5829-3 (PRINT)

ISBN 978-92-893-5830-9 (PDF)

ISBN 978-92-893-5831-6 (EPUB)

http://dx.doi.org/10.6027/ANP2018-820

(C) Pohjoismaiden ministerineuvosto 2018

Ulkoasu: Mette Agger Tang

Paino: Rosendahls

Printed in Denmark

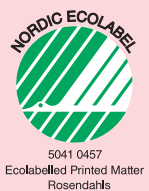

\section{Pohjoismainen yhteistyö}

Pohjoismainen yhteistyö on yksi maailman laajimmista alveellisista yhteistyömuodoista. Yhteistyön piiriin kuuluvat Islanti, Norja, Ruotsi, Suomi ja Tanska sekä Ahvenanmaa, Färsaaret ja Grönlanti.

Pohjoismaista yhteistyötä tehdään politiikan, talouden ja kulttuurin aloilla tärkeänä osana eurooppalaista ja kansainvälistä yhteistyötä. Pohjoismaisen yhteisön tavoitteena on vahva Pohjola vahvassa Euroopassa.

Pohjoismainen yhteistyö pyrkii vahvistamaan pohjoismaisia ja alveellisia etuja ja arvoja globaalissa maailmassa. Maiden yhteiset arvot lujittavat osaltaan Pohjolan asemaa yhtenä maailman innovatiivisimmista ja kilpailukykyisimmistä alueista. 


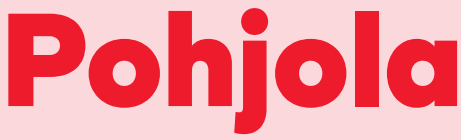

tilastoina

2018 
Kuviot perustuvat pohjoismaisesta

tilastotietokannasta saatuihin tilastoihin.

Tietokanta koostuu monipuolisesta pohjoismaisesta tilastotiedosta, joka on kerätty muun muassa kansallisista tilastokeskuksista sekä kansainvälisten organisaatioiden tilastoista.

\section{Lisää tilastoja osoitteessa www.norden.org/tilastoja}




\section{Esipuhe}

Tämä taskukokoinen Pohjola tilastoina 2018 antaa katsauksen lukuihin, jotka kuvaavat Pohjolan yhteiskuntia.

Pohjoismaat ovat yksittäin pieniä, mutta yhdessä niiden merkitys kasvaa. Jotta Pohjolaa voi tarkastella kansainvälisestä näkökulmasta, olemme lisänneet pohjoismaisten lukujen rinnalle kansainvälisiä lukuja. Tiesitkö, että Pohjoismaiden tavaravienti on yhtä suuri kuin kaksi kolmasosaa Japanin viennistä? Tai että Pohjola on pinta-alaltaan suurempi kuin Intia, mikä tekee siitä maailman seitsemänneksi suurimman alveen?

Tämän kirjasen teemat kuvastavat pohjoismaisen yhteistyön tärkeitä teemoja, kuten lapsia ja nuoria, sukupuolten tasaarvoa sekä kestävyyttä. Vaikka Pohjoismaat ovat hyvin samanlaisia, niiden välillä voi olla suuriakin eroja.

Mikäli haluat tutustua pohjoismaisiin tilastoihin tarkemmin, vieraile osoitteessa norden.org/tilastoja. Sivustosta pääsee myös pohjoismaiseen tilastotietokantaan, jossa on lisää mielenkiintoisia lukuja vertailtavaksi.

Mukavia lukuhetkiä! 
Tanska

DK

Färsaaret

FO

Grönlanti

GL

Suomi

$\mathrm{FI}$

Ahvenanmaa

AX

Islanti

IS

Norja

NO

Ruotsi

SE

Pohjoismaat

NR

Euroopan unioni

EU 


\section{Sisältö / aihealueet}

Pohjoismaat ............................................................................... 8

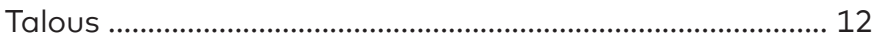

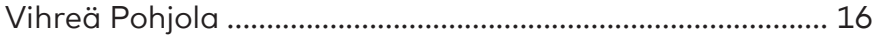

Tasa-arvo, elinkeinoelämä ja työ ............................................ 20

Hyvinvointi ................................................................................ 24

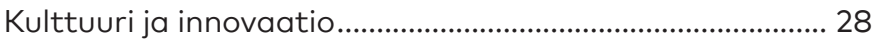

Lapset ja nuoret......................................................................... 32 


\section{Pohjoismaat}

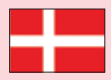

\section{Tanska}

Pinta-ala km²

42926

Väkiluku

5781190

Valtiomuoto

Perustuslaillinen monarkia

Valtionpäämies

Pääkaupunki

Kuningatar Margareeta II

Kööpenhamina

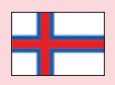

\section{Färsaaret}

Pinta-ala km²

Väkiluku

Valtiomuoto

Valtionpäämies

Pääkaupunki

\section{6}

50498

Itsehallinto, osa Tanskan kuningaskuntaa Kuningatar Margareeta II

Tórshavn

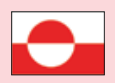

\section{Grönlanti}

Pinta-ala km²

Väkiluku

2166086

Valtiomuoto

Valtionpäämies

Pääkaupunki

\section{7}

Itsehallinto, osa Tanskan kuningaskuntaa Kuningatar Margareeta II

Nuuk

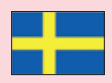

\section{Ruotsi}

Pinta-ala km²

447435

Väkiluku

10120242

Valtiomuoto

Perustuslaillinen monarkia

Valtionpäämies

Pääkaupunki

Kuningas Kaarle XVI Kustaa

Tukholma 

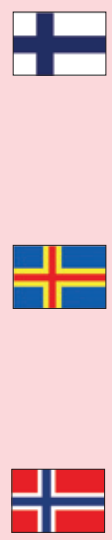

\section{Norja}

Pinta-ala km²

Väkiluku

Valtiomuoto

Valtionpäämies

Pääkaupunki

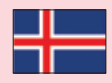

\section{Islanti}

Pinta-ala km²

Väkiluku

Valtiomuoto

Valtionpäämies

Pääkaupunki
338430

5513130

Tasavalta

Presidentti Sauli Niinistö

Helsinki

\section{3}

29489

Itsehallinto, osa Suomen tasavaltaa

Presidentti Sauli Niinistö

Maarianhamina

\section{8}

5295619

Perustuslaillinen monarkia

Kuningas Harald V

Oslo

103492

348450

Tasavalta

Presidentti Guðni Jóhannesson

Reykjavik 


\section{Väkiluku}

miljoonaa (2017)

POHJOISMAAT

27 蚶

EU

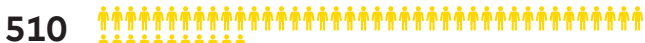

JAPANI

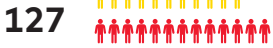

YHDYSVALLAT

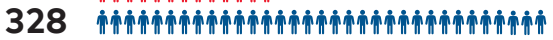

\section{Asukastiheys}

asukkaita/ $/ \mathrm{km}^{2}$ (2017)

POHJOISMAAT 17

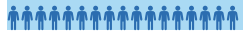

JAPANI 348

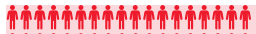

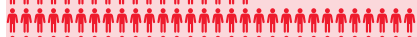


ำ

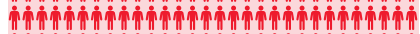



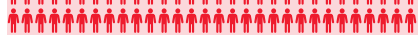

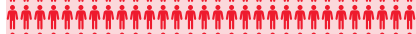

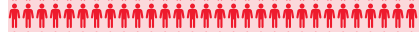

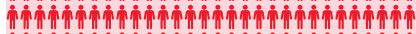

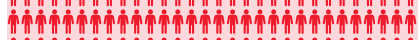

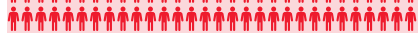

EU 118

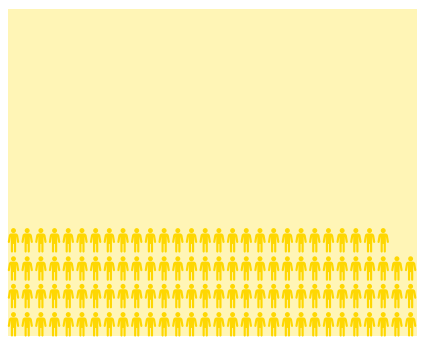

YHDYSVALLAT 35

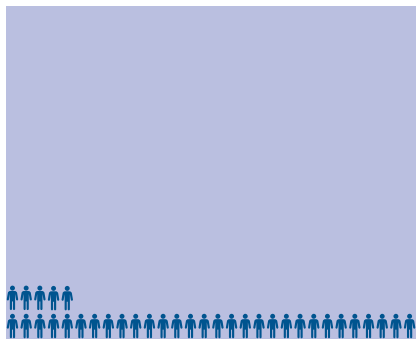


Kokonaispinta-ala

$1000 \mathrm{~km}^{2}$ (2017)

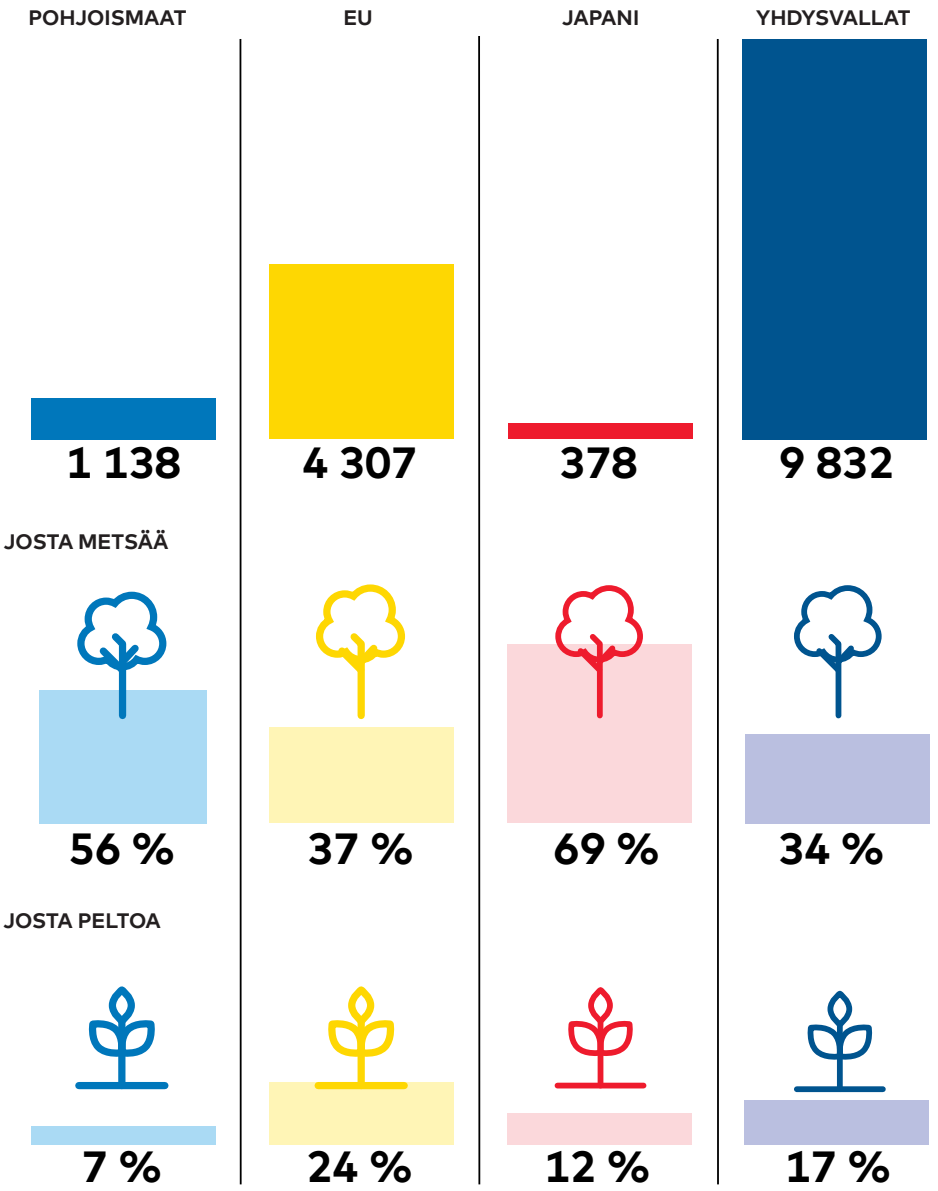




\section{Talous}

\section{Työttömyys}

prosenttia 15-64-vuotiaista (2017)

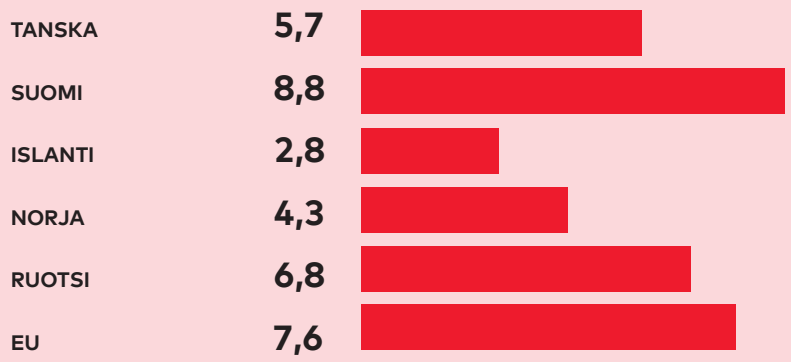



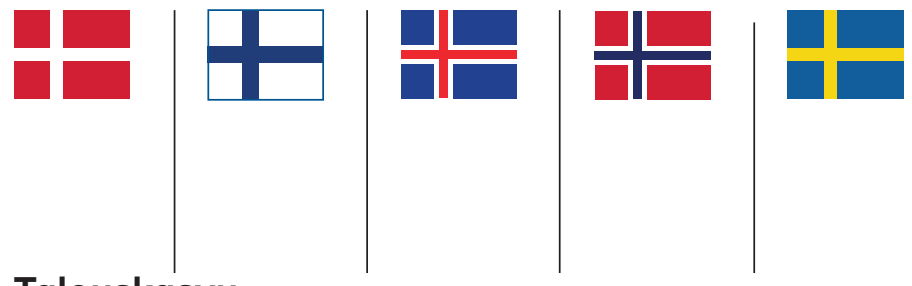

\section{Talouskasvu}

prosenttia (2017)

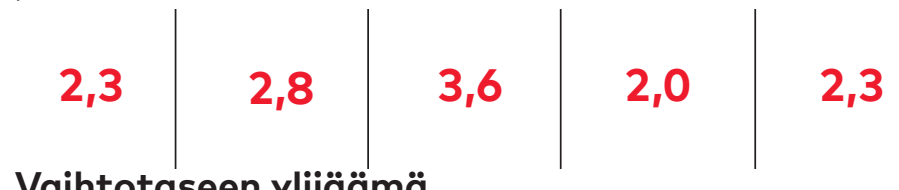

Vaihtotaseen ylijäämä

prosenttia BKT:sta (2017)

Korko

$$
\begin{array}{l|l|l|l|l}
7,6 & 0,7 & 3,4 & 5,5 & 3,3
\end{array}
$$

prosenttia (2017)
0,5
0,5
2,2
1,6
0,7

Julkisen sektorin ylijäämä

prosenttia BKT:sta (2017)

$$
\begin{array}{l|l|l|l|l}
1,0 & -0,6 & 1,5 & 4,4 & 1,3
\end{array}
$$

Kuluttajahintojen nousu prosenttia (2017)

$$
\begin{array}{l|l|l|l|l}
1,1 & 0,8 & -1,7 & 1,9 & 1,9
\end{array}
$$




\section{BKT}

miljardia, PPP, USD (2017)

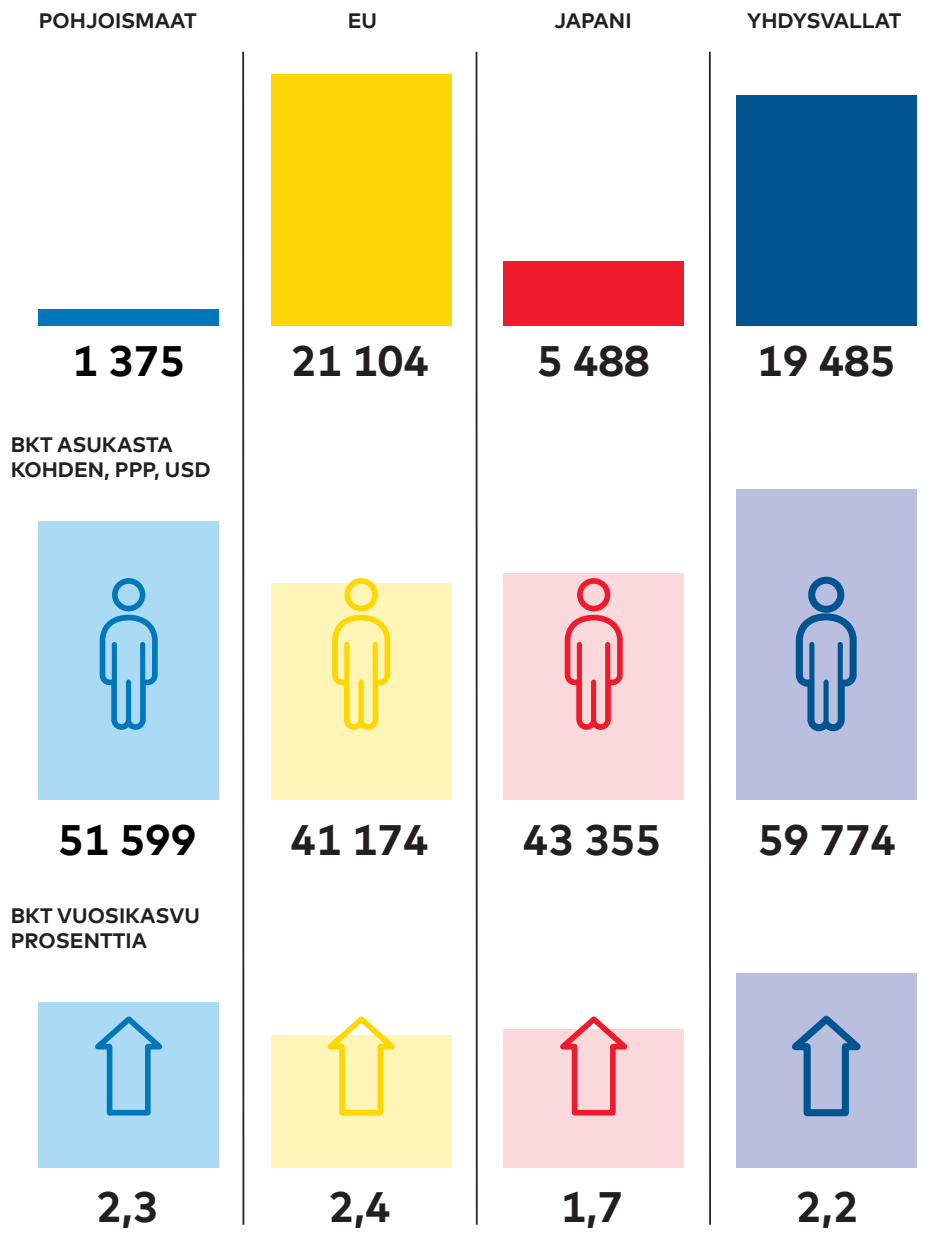




\section{Verot}

prosenttia BKT:sta (2016)

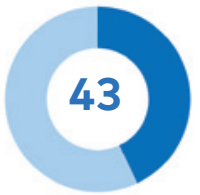

POHJOISMAAT
37

EU
31

JAPANI

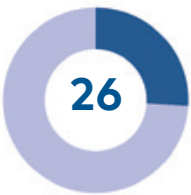

YHDYSVALLAT

\section{Tuonti ja vienti}

mrd. Yhdysvaltain dollaria (2017)

2000

1500

1000

500

0

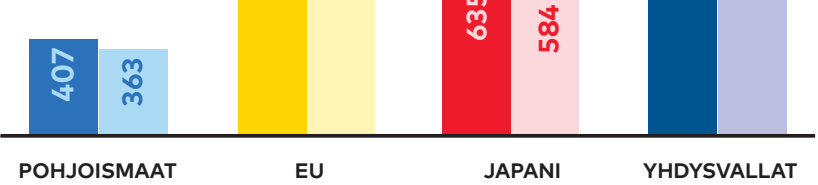




\section{Vihreä Pohjola}

\section{Uusiutuva energia}

prosenttia energian loppukäytöstä (2016)

TANSKA

SUOMI

ISLANTI

NORJA

RUOTSI

EU
32

39

73

69

54

17 

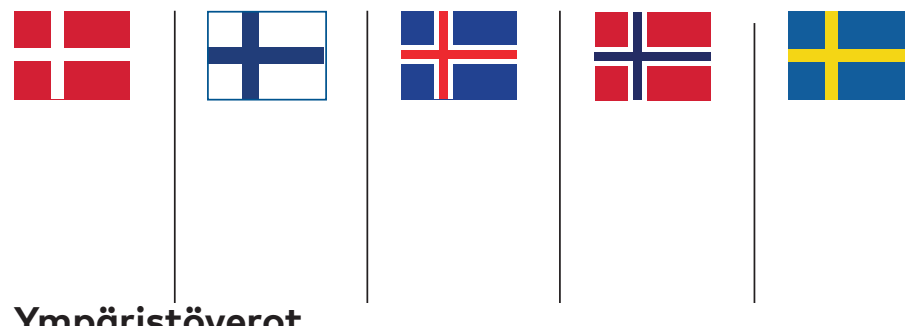

prosenttia kaikista veroista (2016)

Energiaintensiteetti



TJ:a miljoonaa BKT-yksikköä kohden (2016)

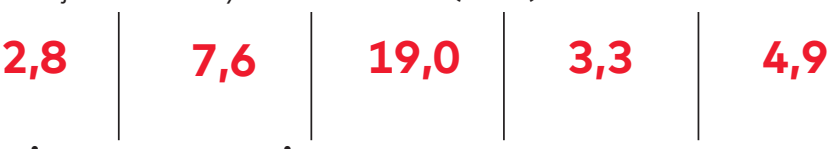

\section{Uusiutuvan energian tuotanto}

prosenttia energian tuotannosta (2016)

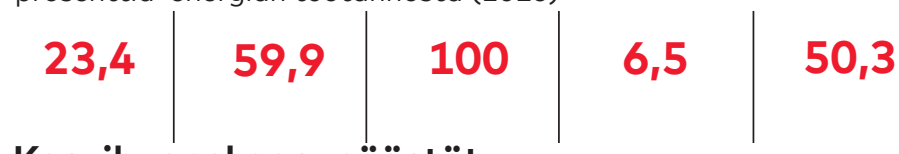

\section{Kasvihuonekaasupäästöt}

tonnia asukasta kohden (2015)

\section{Kunnallisjätteen kierrätys}

$$
\begin{array}{l|r|r|r|r}
9,3 & 10,2 & 13,8 & 10,4 & 5,5
\end{array}
$$

prosenttia kierrätetyistä jätteistä (2016)

$$
\begin{array}{l|l|l|l|l}
28,6 & 29,2 & 25,5 & 28,0 & 32,6
\end{array}
$$




\section{Ympäristökuormituksen irtikytkentä talouskasvusta, Pohjoismaat \\ $2000=100$}



\section{Ympäristökuormituksen irtikytkentä talouskasvusta, EU}

$2000=100$

130

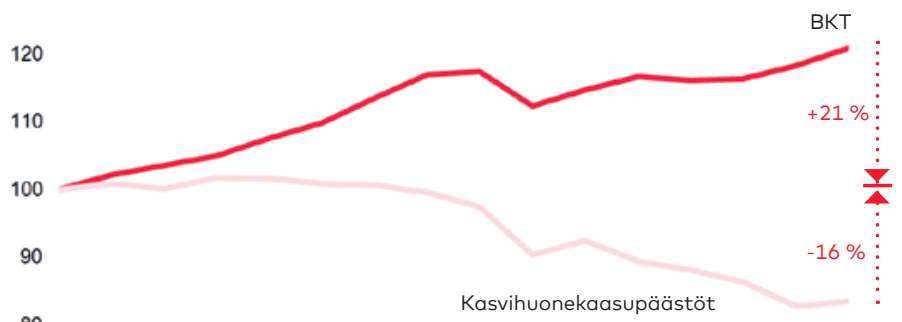

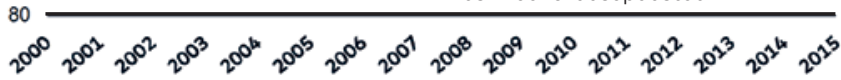




\section{Uusiutuvan energian kulutus}

(2015)

TANSKA

SUOMI

ISLANTI

NORJA

RUOTSI

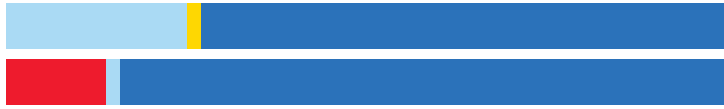

EU
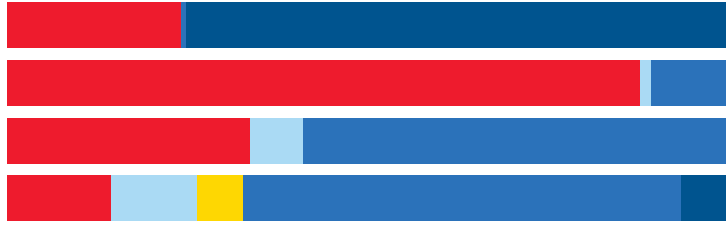

- Vesivoima

Tuulivoima

Aurinkoenergia

- Biomassa ja biojäte

- Geoterminen energia

\section{Kotoperäiset energialähteet}

(2015)



- Hiili Öljy $\quad$ Kaasu

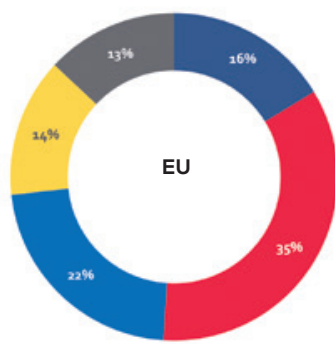

Ydinvoima

- Uusiutuva energia 


\section{Tasa-arvo, elinkeinoelämä ja työ}

Naisten osuus suurten pörssiyhtiöiden hallituksissa

prosenttia (2017)

TANSKA

SUOMI

ISLANTI

NORJA

RUOTSI

EU
29

33

43

43

36

25



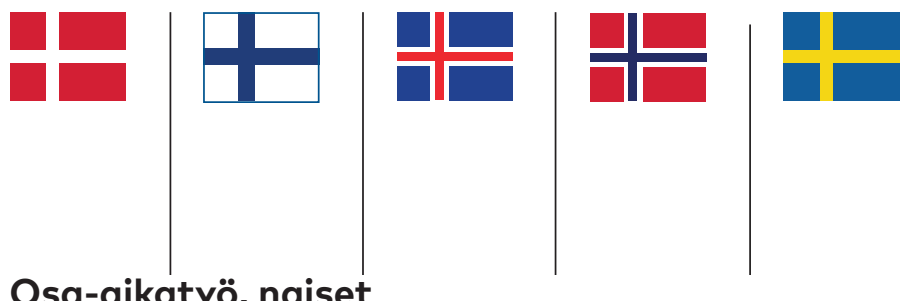

prosenttia 15-64-vuotiaista (2017)

Osa-aikatyö, miehet

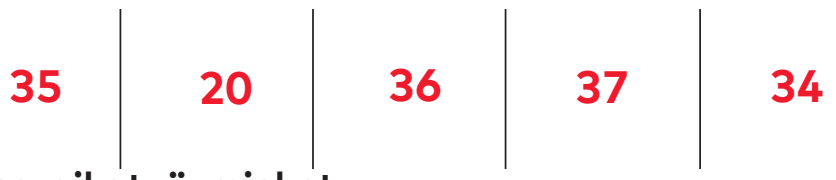

prosenttia 15-64-vuotiaista (2017)

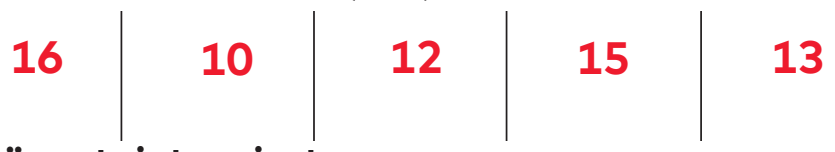

Työnantajat, naiset

prosenttia työllisistä, jotka ovat työnantajia (2016)
1,8
1,9
2,1
0,9
1,6

Työnantajat, miehet

prosenttia työllisistä, jotka ovat työnantajia (2016)
4,6
5,8
5,4
2,6
5,2

Naisten osuus kansallisissa parlamenteissa prosenttia (2016)



Tasa-arvo, elinkeinoelämä ja työ 21 


\section{Työllisyysaste}

prosenttia kaikista 15-64-vuotiaista (2017)



\section{Työttömyysaste}

prosenttia kaikista 15-64-vuotiaista (2017)

10

8

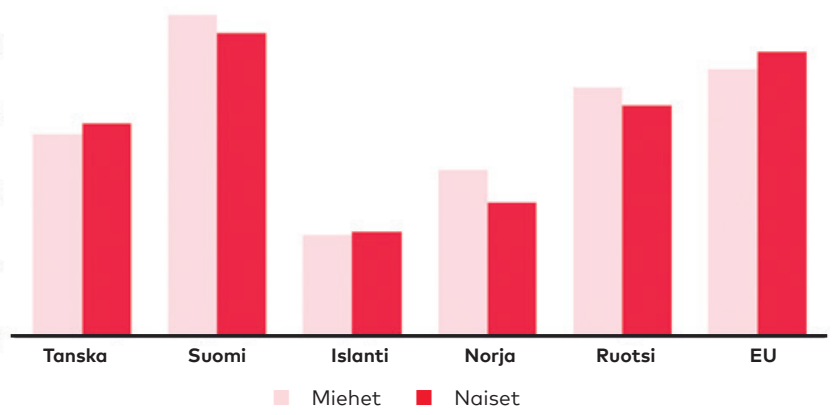

22 Tasa-arvo, elinkeinoelämä ja työ 
Sukupuolten välinen palkkaero prosenttia (2016)

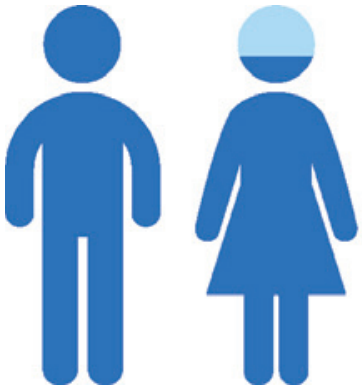

14,9

POHJOISMAAT

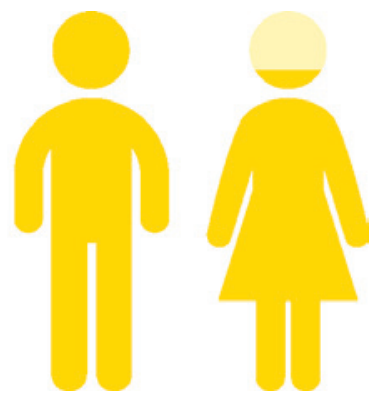

16,2

EU

\section{Isien osuus käytetyistä perhevapaista} prosenttia (2016)


TANSKA

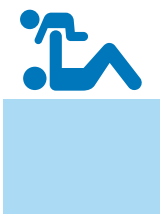

11

SUOMI
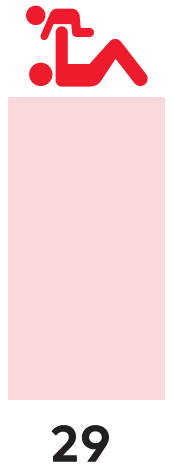

ISLANTI
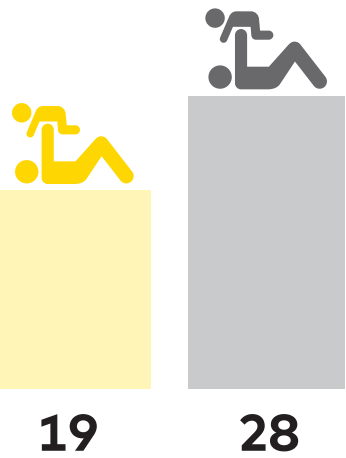

NORJA

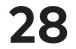

RUOTSI 


\section{Hyvinvointi}

Toimeentulotuen saajat

prosenttia yli 18-vuotiaista (2016)

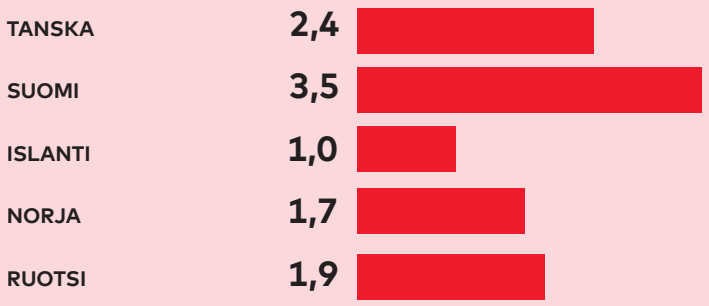



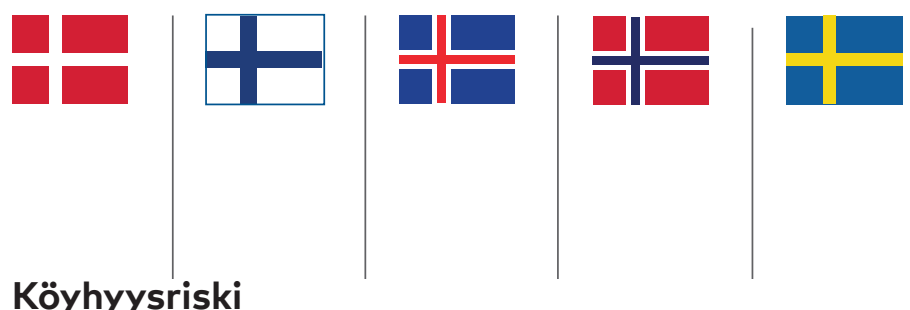

prosenttia yksinhuoltajista, joilla on kotona asuvia lapsia (2016)

\section{Kokonaishedelmällisyysluku}

lasten määrä naista kohden (2016)

$$
\begin{array}{l|l|l|l|l}
1,8 & 1,6 & 1,7 & 1,7 & 1,9
\end{array}
$$

Syövästä johtuvat kuolemat, naiset

100 000:aa asukasta kohden (2015)

\begin{tabular}{l|l|l|l|l}
255 & 186 & 179 & 192 & 218
\end{tabular}

Syövästä johtuvat kuolemat, miehet 100 000:aa asukasta kohden (2015)

288

$$
241 \quad 206
$$

223

239

Terveydenhuollon kustannukset prosenttia BKT:sta (2016)

$$
\begin{array}{l|l|l|l|l}
10,4 & 9,5 & 8,3 & 10,5 & 10,9
\end{array}
$$


Kokonaishedelmällisyysluku

(2017)

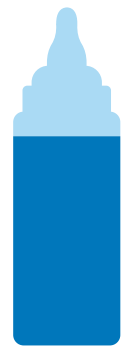

$$
1,8
$$

POHJOISMAAT

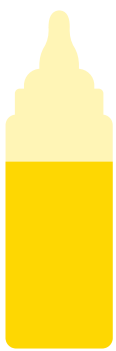

1,6

EU

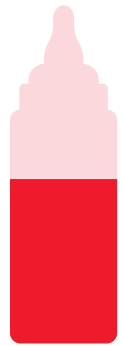

1,4 JAPANI



1,8

YHDYSVALLAT

\section{Elinajanodote}

vuotta (2016)

Naiset



75

80

85

90

- YHDYSVALLAT 81,1 EU 83,6 POHJOISMAAT 83,9 • JAPANI 87,1

\section{Miehet}

75
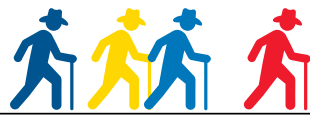

80

85

90

- YHDYSVALLAT 76,1

EU 78,2

- POHJOISMAAT 79,8

- JAPANI 81,0 


\section{Maahanmuutto Pohjoismaihin}

(2016)

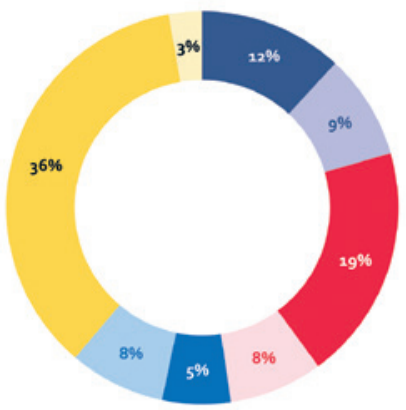

Pohjoismaiden välinen

Puola ja Baltian maat

Muu ETA

Muu Eurooppa

Amerikka

Afrikka

Aasia

Muut

\section{Siirtolaisuus Pohjoismaista}

(2016)

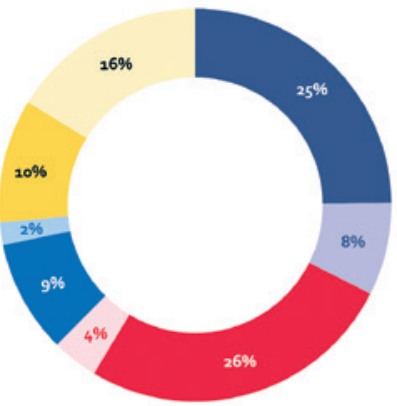

Pohjoismaiden välinen

Puola ja Baltian maat

Muu ETA

Muu Eurooppa

Amerikka

Afrikka

Aasia

Muut 


\section{Kulttuuri ja innovaatio}

Kulttuurin, vapaa-ajan toiminnan ja urheilutoiminnan julkinen rahoitus

prosenttia BKT:sta (2016)

$\begin{array}{ll}\text { TANSKA } & 1,1 \\ \text { SUOMI } & 1,0 \\ \text { ISLANTI } & 2,4 \\ \text { NORJA } & 1,1 \\ \text { RUOTSI } & 1,1 \\ \text { EU } & 0,7\end{array}$




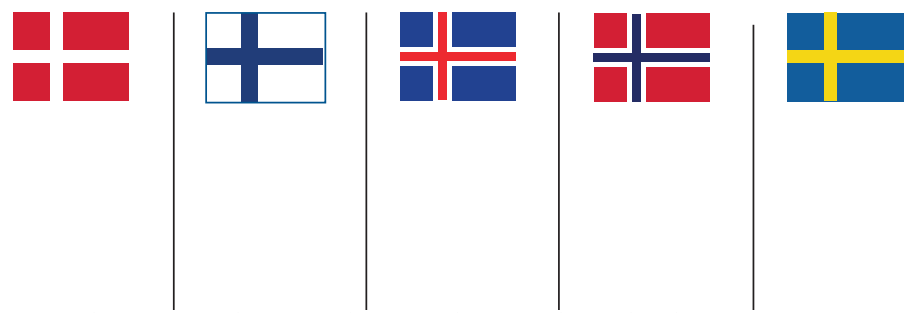

\section{Valtion tutkimus- ja kehittämistoiminnan menot} prosenttia BKT:sta (2016)

Myönnetyt patentit

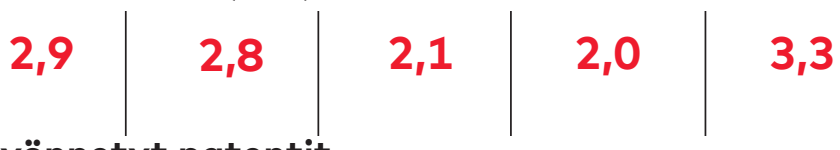

miljoonaa asukasta kohden (2017)

Valmistuneet tutkijat

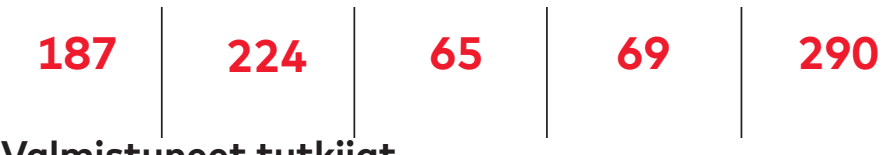

miljoonaa asukasta kohden (2016)

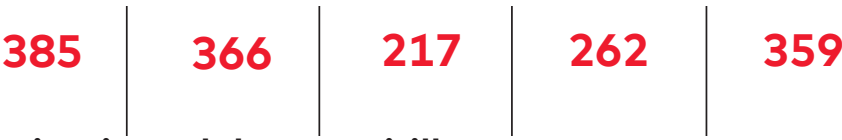

Kotimaiset elokuvaensi-illat

prosenttia kaikista elokuvaensi-illoista (2017 - Islanti 2014)

Museokäynnit

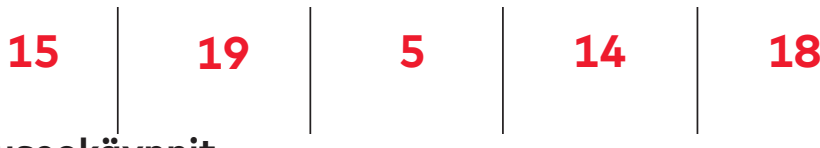

käyntien määrä sataa asukasta kohden (2017 - Islanti ja Ruotsi 2016)

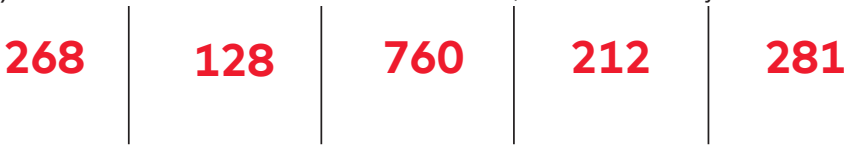

Kulttuuri ja innovaatio 29 


\section{Internet-ostokset}

prosenttia väestöstä (2017)

100

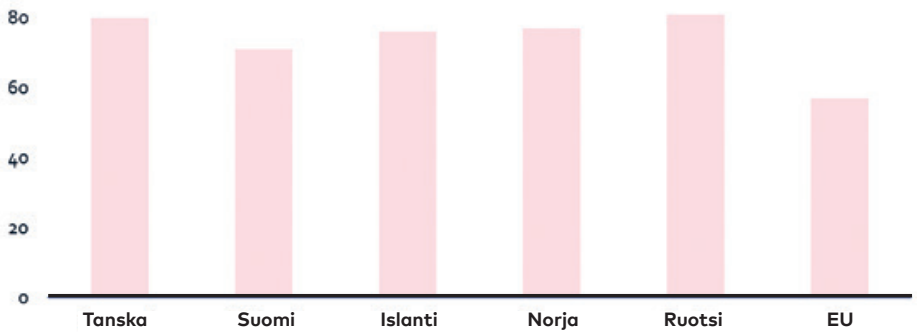

\section{Uudet yritykset}

indeksi $2007=100$



30 Kulttuuri ja innovaatio 


\section{Elokuvakäynnit}

asukasta kohden (2016)

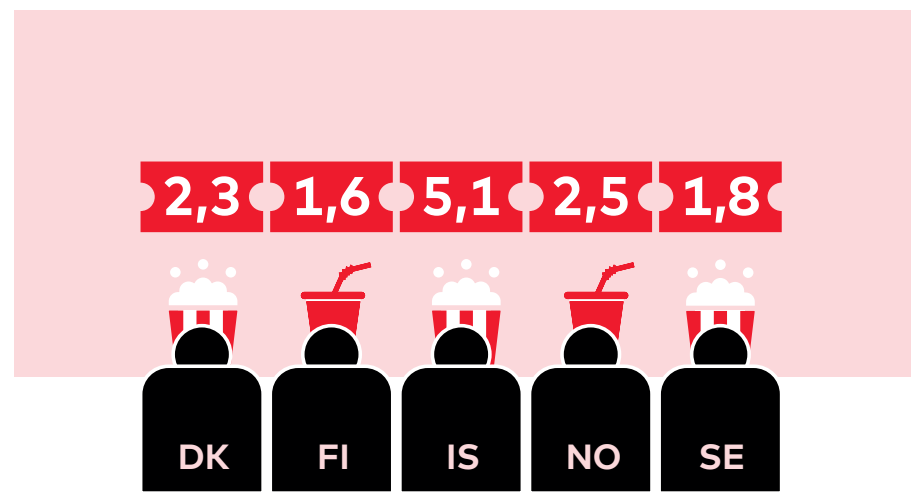

\section{Kulttuurialalla työskentelevät}

prosenttia kokonaistyövoimasta (2016)






\section{Lapset ja nuoret}

Koulutuksen julkinen rahoitus

prosenttia BKT:sta (2016)

TANSKA

SUOMI

ISLANTI

NORJA

RUOTSI

EU

$$
6,9
$$

6,1

7,1

5,6

6,6

4,7
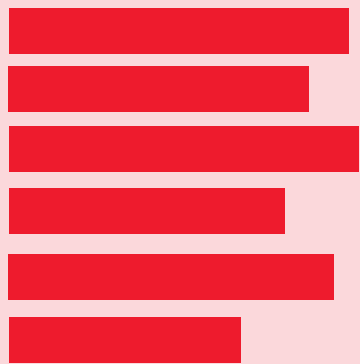


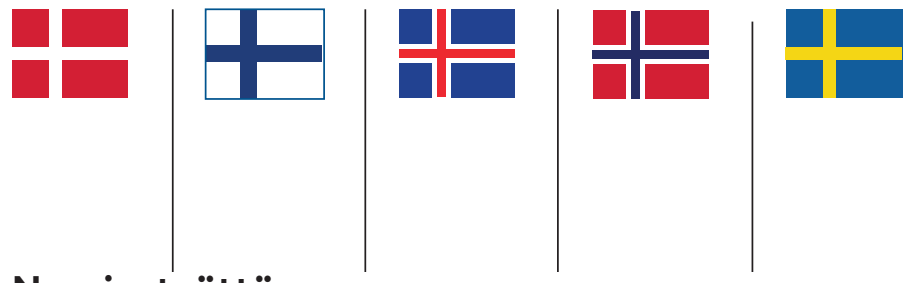

\section{Nuorisotyöttömyys}

prosenttia 15-24-vuotiaista (2017)

Sijoitetut lapset ja nuoret

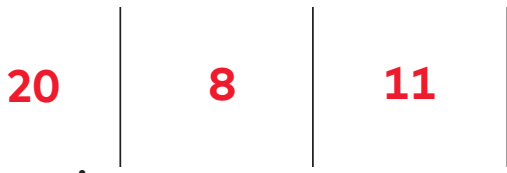

18

1 000:ta henkilöä kohden ikäryhmässä 0-17 vuotta (2015)



Koulutuksesta syrjäytyneet

prosenttia 18-24-vuotiaista (2016)

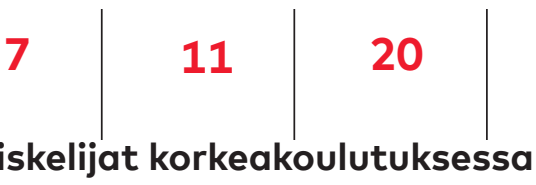

\begin{tabular}{l|l}
7 & 8
\end{tabular}

Opiskelijat korkeakoulutuksessa

prosenttia 20-39-vuotiaista (2015)

PISA
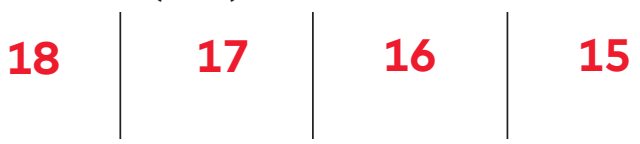

opiskelijoiden suoriutuminen luonnontieteissä (2015)

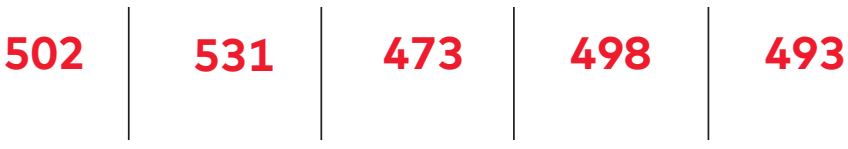




\section{Ulkomailla opiskelevat opiskelijat}

muissa Pohjoismaissa opiskelevien osuus, prosenttia (2015/2016)

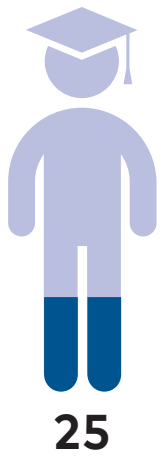

TANSKA



SUOMI
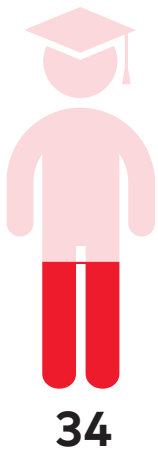

ISLANTI

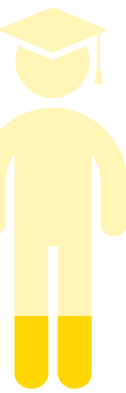

19

NORJA



12

RUOTSI

\section{Taloudellinen tuki opiskelijoille}

euroa/kk (2017)






\section{Suosituimmat vuonna 2017 syntyneiden nimet}

TANSKA

GRÖNLANTI

FÄRSAARET

SUOMI

AHVENANMAA

ISLANTI

NORJA

RUOTSI

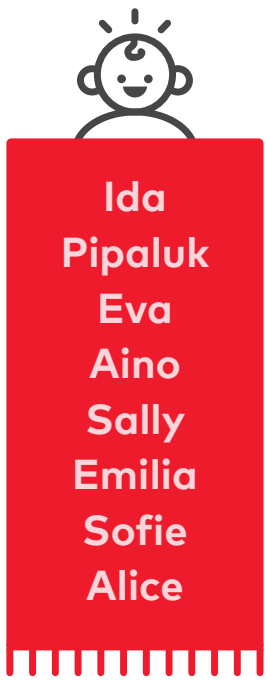


Pohjoismaiden ministerineuvosto

Nordens Hus

Ved Stranden 18

DK-1061 København K

www.norden.org

ANP 2018:820

ISBN 978-92-893-5829-3 (PRINT)

ISBN 978-92-893-5830-9 (PDF)

ISBN 978-92-893-5831-6 (EPUB) 